\title{
The relationship between patient satisfaction and emotional intelligence skills of nurses working in surgical clinics
}

\author{
Gülay Oyur Celik \\ Izmir Katip Celebi Universty, Health \\ Science Faculty, Surgical Nursing \\ Department, Izmir, Turkey
}

This article was published in the following Dove Press journal:

Patient Preference and Adherence

7 August 2017

Number of times this article has been viewed

Objective: The aim of this study was to investigate the relationship between the patient satisfaction and emotional intelligence skills of nurses working in the surgical clinic.

Methods: The study included two groups: a total of 79 nurses working for the surgical clinics of a university hospital in the city of Izmir and a total of 113 inpatients between January 1 and February 20, 2015. The nurses were asked to fill out the Emotional Intelligence Scale and a 12-question self-description form, while the patients were given the Scale of Satisfaction for Nursing Care and an 11-question self-description form.

Results: We found a positive and statistically significant relationship between the satisfaction scores and emphatic concern, utilization of emotions, and emotional awareness subheadings of the patients $(P<0.05)$.

Conclusion: Our study results suggest that emotional intelligence should be one of the determinants of the objectives and that it should be recognized among the quality indicators to improve the quality of health care services.

Keywords: emotional intelligence, patient satisfaction, surgical clinical nursing

\section{Introduction}

Patient satisfaction is of utmost importance for health care services and is usually used as an indicator of the nursing care quality in the clinical setting. ${ }^{1}$ All patients should be evaluated considering their physiological and emotional requirements. It should be kept in mind that they interact with the environment and have emotions, and so they affect the environment. Therefore, each patient should be assessed in a holistic way to increase the satisfaction degree. ${ }^{2}$

Considering the management approaches of the 21 st century, it is evident that the personnel possessing only a high intelligence quotient (IQ) and technical competence are not sufficient for success, instead personnel who are able to understand his own and other individuals' emotions with advanced social competences are needed. ${ }^{3}$ Emotional intelligence (EI) is a term that was first described in 1920 using the interpersonal intelligence model, which is one of Thorndike's multiple intelligence models. ${ }^{4}$ In 1990, Mayer et $\mathrm{al}^{5}$ attempted to scientifically measure the affective domain competencies of individuals and suggested that some of them were better in describing their own emotions, in describing others' emotions, and in solving problems about emotional matters than others. ${ }^{5}$ However, these studies were not considered relevant. The term EI solidified its reputation with the publication of Dr Daniel Goleman's book, “Emotional Intelligence," in 1995. ${ }^{6}$ According to 
Goleman, EI is the individual's competency with which he/she can understand his/her emotions, he/she can show empathy toward others' emotions, and he/she can organize his/her emotions in such a way that he/she can enrich his/her life. ${ }^{5}$ Goleman ${ }^{6}$ describes five basic components in EQ: 1) an individual's awareness of his/her own emotions (self-awareness), 2) an individual's regulation of his/her own emotions (self-regulation), 3) an individual's ability of self-motivation, 4) empathy, and 5) social skills.

It was stated that raising the quality of the nursing practices in health care system was possible with the help of the nurses' EI skills such as effective communication first with the patients and then with their colleagues; being aware of their own feelings; knowing and understanding their patients, using positive coping skills; and having a positive mood. ${ }^{7,8}$ It was stated that those factors helped in meeting the requirements of patients and in reducing the anxieties of nurses, and it also increased the job satisfaction of nurses, and the nurses in turn used their energy to increase the quality of patient care. ${ }^{7-9}$

In the studies carried out about the nurses' EI, it was determined that the professional nurses who applied the integrated approach to the patients, who accommodated privacy, and who knew their patients personally and emotionally faced with both physical and emotional tribulations while they were meeting the patients' requirements, and they used their EI skills while coping with those tribulations. ${ }^{8,10}$

There are a lot of studies in which the relationship between EI and nursing care has been determined, and these are available in the literature. ${ }^{8,10-12}$ Among those studies, the studies in which the importance of EI in communication in psychiatric nursing, in nursing management, and in clinical care was mentioned are seen..$^{8,10-12}$ No studies were conducted regarding the EI of nurses working in surgical clinics.

There is high of patient circulation in surgical clinics, and the nurse gives care to a great number of patients. Therefore, the quality and quantity of the care are closely related to the patient's satisfaction.

When health care personnel recognize EI as the mainstay of success in personal and professional life, patient satisfaction is expected to increase. ${ }^{13}$

Patient-nurse collaboration considerably underlies patient satisfaction. ${ }^{14}$ The support that the patient gets from the nurse, the respect that the nurse shows to the patient, the positive behaviors of the nurse toward the patient, the clear answers of the nurse to solve the patient's problems, and the accessibility of the nurse are the major factors for patient satisfaction. ${ }^{15}$
The accompaniment of the nurse to the patient for a long time makes the patient feel safer, and the nurse has an important task compared to the other health care staff in terms of improving patient satisfaction. ${ }^{15}$

In this sense, the current study was planned to determine the relationship between the use of EI skills by nurses of surgical clinics and patient satisfaction during hospital stay, and also assess the importance of EI skills.

\section{Methods}

\section{Study design}

The study data were collected between January 1 and February 20, 2015. A total of 123 nurses who worked in surgical clinics including general surgery; cardiovascular surgery; urology; orthopedics and traumatology; plastic and reconstructive surgery; neurosurgery; gynecology; and thoracic surgery of a university hospital in Izmir and a total of 256 inpatients who were treated in these clinics were screened. Of the 123 nurses, 44 were not in their working site and refused to participate, and so they were excluded. Of the 256 patients, 113 who met the inclusion criteria and who voluntarily accepted to participate were included. The inclusion criteria were as follows: aged between 18 and 70 years; hospitalization for at least 3 days; scheduled for discharge soon; and ability to read and answer questions. Finally, the study sample comprised a total of 79 nurses and 113 inpatients.

\section{Data collection}

Self-description forms including the sociodemographic data, prepared separately for each group, were administered. A self-description form consisting of 12 questions was used to determine the sociodemographic attributes of the nurses, while a self-description form consisting of 11 questions was used to determine the sociodemographic attributes of the patients. EI Scale (EIS) was administered to the surgical clinic nurses at an opportune time. The patients who were ready for discharge were asked to fill in the Nursing Care Satisfaction Scale (NCSS), without being influenced by anybody, 15 minutes before discharge.

\section{The El scale}

A short 33-item self-report EIS was first developed by Schutte et al ${ }^{16}$ in 1998 to measure the level of EI skills of nurses. Adaptation of the Schutte's scale into Turkish and examination of its psychometric properties were performed by Tatar et al. ${ }^{17}$ The scale consisted of four dimensions including emphatic concern, emotional regulation/management, 
utilization of emotions, and emotional awareness. The reliability factor of the scale was found to be 0.93 in our study. The answers in the scale were of the 5 Likert type and included Strongly Agree (5), Agree (4), Neither (3), Disagree (2), and Strongly Disagree (1). Reverse scoring system was used for Questions 5 and 33 of the scale. However, because the itemtotal correlation coefficient of the Question 5 was found below 0.200 and because it would increase the Cronbach $\alpha$ reliability coefficient, the question was excluded. Finally, the scale was evaluated out of 32 questions in total, including five questions under the Emotional Awareness subheadings. The lowest score was determined as 32 , while the highest score was determined as 160. In addition, 32-74 was a low score, 75-117 indicated moderate score, and 118-160 indicated high score. Higher scores indicated higher EI levels, ie, directly proportional.

\section{The NCSS}

The NCSS was developed by Demir et $\mathrm{al}^{18}$ and consisted of 34 items with validation reliability as the sole factor used to measure the levels of the patients' satisfaction with the nursing care provided. The Cronbach's $\alpha$ coefficient was found to be 0.96 in our study. The answers in the scale were of the 5 Likert type, including Very Dissatisfied (1), Dissatisfied (2), Undecided (3), Satisfied (4), and Very Satisfied (5). Higher scores indicated higher satisfaction levels. The lowest score of the scale was 34, while the highest score was 170 . 34-79 indicated low score, 80-124 indicated moderate score, and 125-170 indicated high score.

\section{Data analysis}

Statistical analysis was performed using the IBM Statistical Package for Social Sciences v22 software (SPSS Inc., Chicago, IL, USA). The Kolmogorov-Smirnov test was used to assess the normality of the distribution. The Mann-Whitney $U$ (post hoc Bonferroni corrected Mann-Whitney $U$ test) and Kruskal-Wallis $H$ tests were used to determine statistical significance. Pearson correlation analysis was carried out to evaluate the relationship between the satisfaction levels of the patients and EIS scores of the nurses. A $P$-value of $<0.05$ was considered statistically significant.

\section{Ethical permission}

This descriptive and cross-sectional study was conducted in accordance with the principles of the Declaration of Helsinki. The study protocol was approved by the Clinical Researches Ethics Committee of Izmir Katip Celebi University.

Electronic (via mail) permission was obtained from Prof Dr Sadegül Akbaba Altun, the author of the Turkish version of the EIS ${ }^{17}$ (Bulletin of Clinical Psychopharmacology - a Turkish journal), for its use in this study.

In order to use the NCSS, electronic (via mail) permission was obtained from Prof Dr Ismet Eşer who made the Turkish translation and assessed the validity-reliability of the scale.

Written and verbal informed consents were obtained from each participant (both patients and nurses).

\section{Results}

The mean age of the 79 nurses was $32.76 \pm 6.4$ years. Of the nurses, $75.0 \%$ were females, and $46.0 \%$ had a bachelor's degree. The mean age of the 113 patients was $49.56 \pm 10.4$ years. Of the 113 patients, $61.0 \%$ were females, and $40.0 \%$ had a primary school level education.

The highest score in the EIS was 160, while the lowest score was 32. Accordingly, the level of EI skills of the nurses was found to be above the mean scores (126.72 \pm 14.4$)$. The highest score in the NCSS was 170, while the lowest score was 34. Accordingly, the levels of the patients' satisfaction with the nursing care provided were found to be above the mean scores (128.52 \pm 24.82$)$.

In addition, a positive and statistically significant relationship was found between the satisfaction scores and the subheading scores for emphatic concern, utilization of emotions, and emotional awareness in the patient group $(P<0.05)$ (Table 1$)$. We also found a statistically significant relationship between the emotional regulation/management subheading and EI general score of the nurses $(P<0.05)$ (Table 2). It was an indicator of the positive relationship between the high levels of EI of the nurses (Cronbach $\alpha=0.93$ ) and the high levels of patient satisfaction (Cronbach $\alpha=0.96)(P<0.05)$ (Table 2).

Furthermore, a positive and statistically significant meaningful relationship was observed between the satisfaction scores of the patients and the subheading scores of emphatic concern, utilization of emotions, and emotional awareness of the nurses $(P<0.05)$. We also found a positive and statistically significant relationship between the emotional regulation/management subheading and EI general scores of the nurses $(P<0.05)$ (Table 3$)$. As seen in Table 3 ,

Table I Total points that the nurses scored in the EIS and that the patients scored in the NCSS

\begin{tabular}{ll}
\hline & Mean (minimum-maximum) \\
\hline EIS & $126.72 \pm 14.4(32-160)$ \\
NCSS & $128.52 \pm 24.82(34-170)$ \\
\hline
\end{tabular}

Abbreviations: EIS, emotional intelligence scale; NCSS, Nursing Care Satisfaction Scale. 
Table 2 Reliability analysis results of the EIS of the nurses and the NCSS of the patients and distribution of average points

\begin{tabular}{llll}
\hline & Number of statements & Cronbach's $\alpha$ & Mean (minimum-maximum) \\
\hline EI - general & 32 & 0.932 & $3.96 \pm 0.45(3.06-5)$ \\
El - emphatic concern & 6 & 0.730 & $3.96 \pm 0.53(2.83-5)$ \\
Emotional regulation/method & 13 & 0.835 & $3.98 \pm 0.46(2.77-5)$ \\
Utilization of emotions & 8 & 0.828 & $3.92 \pm 0.55(2.25-5)$ \\
Emotional awareness & 5 & 0.797 & $3.96 \pm 0.54(2.80-5)$ \\
NCSS - general & 34 & 0.966 & $0.78 \pm 0.73(1.38-5)$ \\
\hline
\end{tabular}

Abbreviations: El, emotional intelligence; EIS, emotional intelligence scale; NCSS, Nursing Care Satisfaction Scale.

we can say that as the nurses' levels of EI increase, the patients' level of nursing care satisfaction also increase.

\section{Discussion}

In the present study, we investigated the relationship between the patient satisfaction and EI skills of the surgical nurses.

In an earlier study, Rego et a ${ }^{19}$ suggested that the EI level of the nurses was the determinant factor for care behaviors. Understanding the patients' emotions, the nurses can recognize the patients' morals, worries, and concerns more clearly, they can give more active importance to the patient's worries, and at the same time, they can be more kindhearted. Depending on the patients' specific situations and emotions, the nurses tend to organize their own care behaviors and to show appropriate communication behaviors to raise the morale of the patients by helping them block out negative thoughts. It should be kept in mind that each patient is special, and his/her experiences should be respected. The patient should be allowed to experience and express his/her emotions, except the apparent ones. The ability to see the patient in an integrated way and the ability to decide what is useful for each patient beyond the scientific data are related to the EI of the nurse. In this way, the nurse would contribute to the excellence of the nursing practice, making the patients feel more positive emotional and psychological reactions. ${ }^{19}$

In the standardization studies carried out in health care services, perceived service quality is regarded as being as important as service quality given ${ }^{20}-$ a relationship in which

Table 3 The relationship between the El points of the nurses and satisfaction points of the patients

\begin{tabular}{lll}
\hline Related & NCSS & \\
\cline { 2 - 3 } & $\boldsymbol{r}$ & $\boldsymbol{P}$-value \\
\hline Emphatic concern & 0.435 & 0.00 \\
Emotional regulation/method & 0.605 & 0.00 \\
Utilization of emotions & 0.407 & 0.00 \\
Emotional awareness & 0.484 & 0.00 \\
El - general & 0.585 & 0.00 \\
\hline
\end{tabular}

Abbreviations: El, emotional intelligence; NCSS, Nursing Care Satisfaction Scale. the sense of mercy, sense of empathy, and similar skills are at the forefront, or in other words, a relationship in which EI is shown to be sufficient to make the patient feel satisfied. ${ }^{14,15}$ This is because the patient - if he/she is not a health care professional - is usually unable to measure the medical knowledge of the health care professional. The tool that the patient uses to measure the quality of the health care service also includes EI. ${ }^{21}$ In a previous study, Caruso et al ${ }^{22}$ reported that psychiatrists, social service experts, elderly care experts, family doctors, physiotherapists, and nurses were the individuals who were expected to have a high level of EI in order to achieve success and satisfaction. ${ }^{22}$ According to McQueen, ${ }^{8}$ and Adams and Iseler ${ }^{23}$ to bring the use of EI to the forefront the nursing profession requires direct communication between the patient and health care service, which can only be made possible by teamwork; that is why EI skills of nurses should be well developed. The use of EI skills by nurses affects their quality of life and even increases their quality of life.

In a 2010 study, Karakas and Kucukogly ${ }^{24}$ measured the EI of nurses, and they reported that the nurses who took part in their study had low scores in the subdimensions of controlling emotions and social skills and that those dimensions needed to be developed. In the present study, the nurses had values above the mean scores in the subdimensions of EI (Cronbach $\alpha=0.93$, mean EI: $3.96 \pm 0.45$ ). Atilla et al, ${ }^{25}$ in their study, showed that there was a positive and close relationship, with 0.01 significance level, between the self-evaluation and regulation of emotions subdimensions of EI and the nursing satisfaction subdimension of patient satisfaction. These findings are also consistent with our study results $(P=0.00)$.

In another study on patient satisfaction, the authors demonstrated that the nurse's behavior toward patient needs was the most important factor that affected the level of patient satisfaction. ${ }^{26}$ Also, Jun et $\mathrm{al}^{27}$ reported that the assessment of patient satisfaction was the mainstay of planning, practicing, and evaluating nursing care. Consistent with the previous findings, the satisfaction from nursing services was found to affect the general patient satisfaction in our studies. ${ }^{28}$ 
The mean score of the patients in the NCSS was found to be 129.63 in the study of Ozer et al, ${ }^{29} 108.76$ in the study of Yurumezoglu, ${ }^{30}$ and 131 in the study of Demir et al. ${ }^{18}$ In our study, it was 128.52. Accordingly, we can conclude that the level of EI skills of the nurses in our study was high. The score of the patients in the NCSS was found to be above the mean score, and, according to those results, our patients were satisfied with nursing care overall.

Nonetheless, further large-scale studies are required to confirm our study findings. We also suggest that programs for developing the EI of nurses, both during their education and during practice, be prepared and nurses encouraged to take part in these programs. The effectiveness of these programs should be measured. The administration can tailor and support these programs to make the programs more effective and to provide more robust scientific data.

\section{Conclusion}

In conclusion, our study results show that as the level of EI skills of nurses increases, the satisfaction level of patients for whom the nursing careis provided also increases. Thus, patient satisfaction is affected by the EI level of the health care providers. Furthermore, it should be kept in mind that the EI skills are not endowments and that they can be learned and developed later. Therefore, EI should be one of the determinants of the objectives and recognized as one of the quality indicators to improve the quality of health care services. The nurses should be given education periodically in order to improve and use EI. EI can be used as a criterion for evaluation of the performances of surgical nurses. Point scoring system can be applied to surgical nurses or to all clinic nurses by comparing it with patient satisfaction. Thus, by providing the clinical use of EI, patient satisfaction can be increased.

\section{Acknowledgments}

We would like to thank the university authorities for granting approval for this study; the authors of the academic scales for allowing us to use their data collection tools and scales, and Mesude Eken who provided full support in carrying out this study.

\section{Disclosure}

The author reports no conflicts of interest in this work.

\section{References}

1. Lake ET, Germack HD, Viscardi MK. Missed nursing care is linked to patient satisfaction: a cross-sectional study of US hospitals. BMJ Qual Saf. 2016;25:535-543.
2. You LM, Aiken LH, Sloane DM, et al. Hospital nursing, care quality, and patient satisfaction: cross-sectional surveys of nurses and patients in hospitals in China and Europe. Int J Nurs Stud. 2013;50: 154-161.

3. Freshman B, Rubino L. Emotional intelligence skills for maintaining social networks in healthcare organizations. Hosp Top. 2004;82(3):2-9.

4. Pal HR, Pal A, Tourani P. Theories of intelligence. Everyman's Sci. 2004;39:181-186.

5. Mayer JD, DiPaolo M, Salovey P. Perceiving affective content in ambiguous visual stimuli: a component of emotional intelligence. JPers Assess. 1990;54:772-781.

6. Goleman D. Emotional intelligence-“Duygusal Zeka.” Turkish Translate: Yüksel BS. 29th ed. Istabul: Varlık; 2005.

7. Freshman B, Rubino L. Emotional intelligence: a core competency for health care administrators. Health Care Manag. 2002;20:1-9.

8. McQueen AC. Emotional intelligence in nursing work. $J$ Adv Nurs. 2004:47:101-108

9. Trivellasa P, Gerogiannisb V, Svarnab S. Exploring work place implications of emotional intelligence (WLEIS) in hospitals: job satisfaction and turnover intentions. Proc Soc Behav Sci. 2013;73:701-709.

10. Rego A, Godinho L, Mcqueen A, Cunha MPE. Nurses' emotional intelligence and caring behaviours: an empirical study. Documentos de Trabalha em Gestao, Universidade De Aveiro, Departamento De Economia, Gestão E Engenharia Industrial. 2007:1-19.

11. Tuncer M, Demiralp M. Relationship between emotional intelligence and communication skills in nurses working in psychiatry clinics: a multicenter study. TAF Prev Med Bull. 2016;15(5):389-395.

12. Codier E, Kooker BM, Shoultz J. Measuring the emotional intelligence of clinical staff nurses: an approach for improving the clinical care environment. Nurs Admin Quart. 2008;32(1):8-14.

13. Akerjordet K, Severinsson E. Emotional intelligence: a review of the literature with specific focus on empirical and epistemological perspectives. J Clin Nurs. 2007;16:1405-1416.

14. Berglund CB, Gustafsson E, Johansson H, et al. Nurse-led outpatient clinics in oncology care - Patient satisfaction, information and continuity of care. Eur J Oncol Nurs. 2015;19:724-730.

15. Evans EC. Exploring the nuances of nurse-patient interaction through concept analysis: impact on patient satisfaction. Nurs Sci Q. 2016; 29:62-70.

16. Schutte NS, Malouff JM, Hall LE, et al. Development and validation of a measure of emotional intelligence. Pers Indiv Diff. 1998;25(2): $167-177$.

17. Tatar A, Tok S, Saltukoglu G. Adaptation of the revised schutte emotional intelligence scale into turkish and examination of its psychometric properties. Bull Clin Psychopharmacol. 2011;21(4):325-338.

18. Demir Y, Arslan GG, Eser I, et al. Bir eğitim hastanesinde yatan hastaların hemşirelik hizmetlerinden memnuniyet düzeylerinin incelenmesi. Istanbul Üniversitesi Florence Nightingale Hemşirelik Dergisi. 2011;19:68-76.

19. Rego A, Godinho L, McQueen A, et al. Emotional intelligence and caring behaviour in nursing. Serv Indus J. 2010;30(9):1419-1437.

20. Alasad J, Abu Tabar N, AbuRuz ME. Patient satisfaction with nursing care: measuring outcomes in an international setting. J Nurs Admin. 2015;45:563-568.

21. Scott J. How healthcare leaders can increase emotional intelligence. Radiol Manage. 2013;(Suppl 11-16):S6.

22. Caruso EM, Cisar N, Pipe T. Creating a healing environment: an innovative educational approach for adopting Jean Watson'sTheory of Human Caring. Nurs Admin Q. 2008;32:126-132.

23. Adams KL, Iseler JI. The relationship of bedside nurses' emotional intelligence with quality of care. J Nurs Care Qual. 2014;29(2):174-181.

24. Karakas SA, Kucukoglu S. Bir Eğitim Hastanesinde Çalışan Hemşirelerin Duygusal Zeka Düzeyleri. Anadolu Hemşirelikve Sağ llk Bilimleri Dergisi. 2011;14:8-13.

25. Atilla G, Carikci IH, Erdem R. Hastanelerde Duygusal Zeka-Hasta Memnuniyeti İlişkisi: Isparta İl Merkezi Örneği. Afyon Kocatepe Üniversitesi İktisadi ve İdari Bilimler Fakültesi Dergisi. 2013;15:101-119. 
26. Spagnola S, Zabora J, BrintzenhofeSzoc K, et al. The Satisfaction with Life Domains Scale for Breast Cancer (SLDS-BC). Breast J. 2003;9:463-471.

27. Jun EY, Oh H. Patient needs and satisfaction with nursing care after day surgery based on a patient-centered care framework. Clin Nurs Res. Epub 2016 Feb 24.

28. Tekin F, Findik UY. Level of perception of individualized care and satisfaction with nursing in orthopaedic surgery patients. Orthop Nurs. 2015;34:371-374.
29. Özer A, Çakı1 E. Sağlık Hizmetlerinde Hasta Memnuniyetini Etkileyen Faktörler. Tip Araştırmaları Dergisi. 2007;5:140-143.

30. Arslan Yürümezoğlu H, Koçkar C. Yataklı tedavi kurumlarında çalışan hemşirelerin iş doyumları ve hastaların hemşirelik hizmetinden memnuniyeti. Yayınlanmamış Yüksek Lisans Tezi, Dokuz Eylül Üniversitesi Sağlık Bilimleri Enstitüsü. İzmir. 2007.

\section{Publish your work in this journal}

Patient Preference and Adherence is an international, peer-reviewed, open access journal that focuses on the growing importance of patient preference and adherence throughout the therapeutic continuum. Patient satisfaction, acceptability, quality of life, compliance, persistence and their role in developing new therapeutic modalities and compounds to optimize clinical outcomes for existing disease states are major areas of interest for the journal. This journal has been accepted for indexing on PubMed Central. The manuscript management system is completely online and includes a very quick and fair peer-review system, which is all easy to use. Visit http://www dovepress.com/testimonials.php to read real quotes from published authors.

Submit your manuscript here: http://www.dovepress.com/patient-preference-and-adherence-journal 